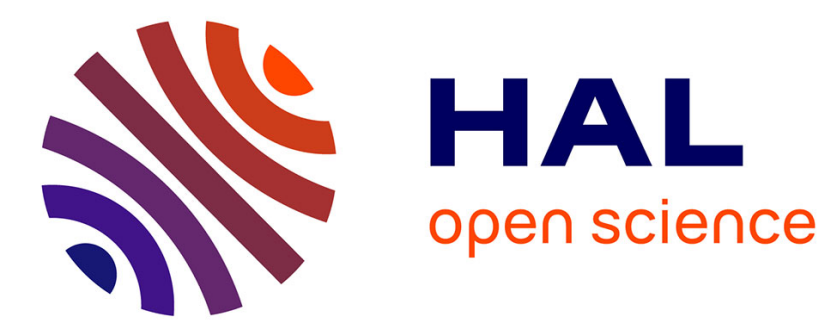

\title{
De novo expression of EphA2 in osteosarcoma modulates activation of the mitogenic signaling pathway
}

Raphaela Fritsche, Aurelia Noske, Ute Ungethüm, Ralf-Jürgen Kuban, Peter

M Schlag, Per-Ulf Tunn, Janine Karle, Veit Jonas Krenn, Manfred Dietel, Christine Sers

\section{To cite this version:}

Raphaela Fritsche, Aurelia Noske, Ute Ungethüm, Ralf-Jürgen Kuban, Peter M Schlag, et al.. De novo expression of EphA2 in osteosarcoma modulates activation of the mitogenic signaling pathway. Histopathology, 2010, 57 (6), pp.836. 10.1111/j.1365-2559.2010.03713.x . hal-00601183

\section{HAL Id: hal-00601183 https://hal.science/hal-00601183}

Submitted on 17 Jun 2011

HAL is a multi-disciplinary open access archive for the deposit and dissemination of scientific research documents, whether they are published or not. The documents may come from teaching and research institutions in France or abroad, or from public or private research centers.
L'archive ouverte pluridisciplinaire HAL, est destinée au dépôt et à la diffusion de documents scientifiques de niveau recherche, publiés ou non, émanant des établissements d'enseignement et de recherche français ou étrangers, des laboratoires publics ou privés. 


\section{Histopathology}

\section{De novo expression of EphA2 in osteosarcoma modulates activation of the mitogenic signaling pathway}

\begin{tabular}{|r|l|}
\hline Journal: & Histopathology \\
\hline Manuscript ID: & HISTOP-08-09-0449.R1 \\
\hline Manuscript Type: & Original Article \\
\hline Date Submitted by the & A8-Feb-2010 \\
\hline Complete List of Authors: & $\begin{array}{l}\text { Fritsche, Raphaela; Charite Universitätsmedizin Berlin, Institut of } \\
\text { pathology } \\
\text { Noske, Aurelia } \\
\text { Ungethüm, Ute } \\
\text { Kuban, Ralf-Jürgen } \\
\text { Schlag, Peter } \\
\text { Tunn, Per-Ulf } \\
\text { Karle, Janine } \\
\text { Krenn, Veit } \\
\text { Dietel, Manfred } \\
\text { Sers, Christine; Institute of Pathology, Charité - } \\
\text { Universitätsmedizin Berlin }\end{array}$ \\
\hline Keywords: & EphA2, EFNA1, MAPK, Osteosarcoma \\
\hline
\end{tabular}

\section{ScholaroNE \\ Manuscript Central}


De novo expression of EphA2 in osteosarcoma modulates activation of the mitogenic signaling pathway

Raphaela Fritsche-Guenther ${ }^{1}$, Aurelia Noske ${ }^{1}$, Ute Ungethüm ${ }^{2}$, Ralf-Jürgen Kuban ${ }^{2}$, Peter M. Schlag $^{3}$, Per-Ulf Tunn ${ }^{3}$, Janine Karle $^{1}$, Veit Krenn ${ }^{4}$, Manfred Dietel $^{1}$, Christine Sers ${ }^{1}$

${ }^{1}$ Institute of Pathology, Charitè Universitätsmedizin Berlin, Berlin, Germany

${ }^{2}$ Laboratory for Functional Genome Research, Charitè Universitätsmedizin Berlin, Berlin, Germany

${ }^{3}$ Robert-Rössle-Klinikum, Charitè Universitätsmedizin Berlin, Berlin, Germany

${ }^{4}$ Center for Histology, Cytology and molecular Diagnostic, Wissenschaftspark Trier, Trier, Germany

\section{Corresponding author:}

Dr. rer. nat. Raphaela Fritsche

Charitè Universitätsmedizin Berlin

Institute of Pathology

Chariteplatz 1

D-10117 Berlin

Fon: $\quad$ +4930450536185

Fax: $\quad$ +4930450536909

E-mail: $\quad$ raphaela.fritsche@ charite.de

Running title: $\quad$ Ephrin expression in osteosarcoma

Key words: $\quad$ EphA2, EFNA1, MAPK, osteosarcoma 


\begin{abstract}
Aims: In osteosarcoma patients, the development of metastases, often to the lungs, is the most frequent cause of death. To improve this situation, a deeper understanding of the molecular mechanisms governing osteosarcoma development and dissemination and the identification of novel drug targets for an improved treatment are needed. Methods and results: Towards this aim, we characterized osteosarcoma samples using genome-wide microarrays and detected increased expression of the EphA2 receptor and its ligand EFNA1 in osteosarcoma tissues. In addition, increased expression of EFNB1, EFNB3 and EphA3 was suggested. Immunohistochemical staining revealed an absence of EphA2 from normal bone, and de novo expression in osteosarcomas. EFNA1 was expressed in normal bone, but significantly elevated in tumors. This pattern suggests a specific role for the EFNA1-EphA2-interaction in osteosarcoma. Further in vitro investigations on the functional role of EphA2 and EFNA1 showed that EFNA1 ligand binding induced increased tyrosine phoshorylation, receptor degradation and downstream MAPK activation. Interference with the MAPK pathway unraveled a potential autoregulatory loop governing mainly EFNA1 expression via the same pathway. Conclusion: Our results indicate that upregulation and de novo expression of ephrins in osteosarcomas are involved in oncogenic signaling and thus might stimulate osteosarcoma metastasis.
\end{abstract}




\section{Introduction}

Conventional osteosarcoma, also called classical osteosarcoma, is the most common malignant primary bone tumor in children and adolescents with a profound risk of metastasis to the lung ${ }^{1}$. This highly aggressive neoplasm mainly affects patients in the second decade of life when the growth spurt is highest, with $60 \%$ of patients under the age of $25^{2}$. Before the use of effective chemotherapy, the 2-year overall survival rates for patients with osteosarcomas was $15 \%$ to $20 \%$ following surgical resection and/or radiotherapy ${ }^{3}$. Surgery and chemotherapy since then led to an improvement in long-term survival rates to $50 \%$ to $80 \%{ }^{4}$. Nevertheless, drug resistance and poor clinical outcome due to early metastasis are still a problem.

Using microarray analysis we recently detected several ephrins and their cognate receptors deregulated in human bone tumors such as giant cell tumors and chondrosarcomas ${ }^{5}$. Ephrin receptors (Eph) are the largest group of receptor tyrosine kinases, however to date most information about ephrin receptors and ephrin ligands (EFN) was gained from melanoma and epithelial tumors ${ }^{6}$. In mouse melanoma cells, expression of the EphA2 receptor was shown to stimulate a distinct invasion program resulting in metastasis formation $^{7}$. In carcinomas, there is already ample information on the diverse roles of different EFN and Eph and their signaling ${ }^{8}$. In colorectal cancer, loss of the EphA1 protein has been correlated with invasion and metastasis and is therefore associated with a poor prognosis ${ }^{9,10}$. In contrast, EphA2 was found upregulated in many carcinomas and exhibits both a kinasedependent and kinase independent role in the metastasis of prostate cancer ${ }^{11}$. The research on ephrin involvement in tumor development and progression is complicated by the fact that ephrin receptors and their ligands display forward and reverse signaling, yet the impact of both EphA and B family members in angiogenesis is now well documented ${ }^{12}$. 
Based on current molecular knowledge, targeted and rational therapeutic strategies are developed and nowadays successfully improve survival of cancer patients. Nevertheless, there is a continued medical need to study the basic molecular mechanisms of osteosarcoma in order to develop bone tumor-specific therapeutic strategies. The current study aimed to identifying genes differentially expressed between normal human osteoblasts and osteosarcoma tissue and to define genes that may be involved in tumor progression. This analysis revealed a distinct ephrin expression pattern and an increased expression of EFNA1 ligand and EphA2 receptor in human osteosarcoma tissue.

\section{Material and methods}

\section{Patients and tissues}

Tumor samples were obtained from the Max-Delbrueck-Center, division of Pathology, BerlinBuch, Germany. Patient characteristics are described in Tab. 1. The tissue specimens were fixed in $4 \%$ neutral buffered formaldehyde, bone containing tissue was EDTA-decalcified and embedded in paraffin. For each case, hematoxylin and eosin (H\&E)-stained slides were carefully reviewed and the diagnosis of the tumor was confirmed according to WHO criteria. Written informed consent was obtained from each patient. The median age of osteosarcoma patients is 37 and ages vary from 7 years to 74 years. This is unusual as osteosarcoma typically affects adolescents, but we were not able to use younger patients based on the fact, that our sample collection in the institute include only these patients. All of the osteosarcoma tumors are primary.

\section{Cell culture}

Primary osteoblast cells $(\mathrm{HOBc})$ and the osteosarcoma cell line SaOS2 were purchased from Provitro GmbH, Berlin, Germany and from ATCC (American Type Culture Collection) and 
cultured in osteoblast growth medium (PromoCell, Heidelberg, Germany) and McCoys5A media (Gibco) supplemented with $10 \%$ fetal calf serum and $1 \%$ penicillin/streptomycin, respectively. The osteosarcoma cell lines HOS, MNNG/HOS, OST, SJSA, MG63 and ZK58 were a gift from Prof. Dr. G. Gaedicke, Clinic for General Pediatrics and Experimental Oncology, Charité Universitätsmedizin Berlin, Berlin, Germany and cultured in RPMI1640 (Biochrome) supplemented with $10 \%$ fetal calf serum and $1 \%$ penicillin/streptomycin. All cells were incubated in a humidified atmosphere with $5 \% \mathrm{CO}_{2}$ at $37^{\circ} \mathrm{C}$. For signaling pathway analyses $1 \mu \mathrm{g} / \mathrm{ml}$ EFNA1/F $(\mathrm{F} \& D), 50 \mu \mathrm{M}$ U0126 (Promega) or 50 $\mu \mathrm{M}$ DMSO (Sigma) were used for the time points indicated. For proliferation assays cells were directly plated on 96plates or $96-$ polyhema-plates and treated with $1 \mu \mathrm{g} / \mathrm{ml}$ EFNA1/F $\mathrm{F}_{\mathrm{c}}$ up to $96 \mathrm{~h}$. For anchorageindependent growth media containing EFNA1/ $\mathrm{F}_{\mathrm{c}}$ was changed every $24 \mathrm{~h}$. Proliferation of cells was measured using the MTT cell proliferation kit (Roche). For wound healing assay, cells were grown on 6-Well dishes or glass slides as a confluent monolayer and wounded with a $10 \mu \mathrm{l}$ pipette tip. Afterwards, $1 \mu \mathrm{g} / \mathrm{ml}$ EFNA1/F $\mathrm{F}_{\mathrm{c}}$ in the presence of fetal calf serum was added and wound closure was observed up to 48 hours.

\section{Microarray analysis}

All tissues were cryopreserved in liquid nitrogen immediately after removal and stored at $-80^{\circ} \mathrm{C}$. RNA was isolated from frozen samples and fresh cells using Tri-Reagent (Sigma) as well as the Rneasy-mini-kit (Qiagen). cRNA was synthesized from $5 \mu \mathrm{g}$ of total RNA. Synthesis of biotin-labeled cRNA was performed using the BioArray High Yield RNA Transcription kit (Enzo Diagnostics, Farmingdale, N.Y.). The amplified cRNA was hybridized to HG U133A arrays (Affymetrix, Santa Clara, CA). After a scan of the array surface, the computer-generated image of the array was overlaid with a virtual grid, controlled by Microarray Suite 5.0 software (Affymetrix). The Data Mining Tool 3.0 (Affymetrix) and GeneSpring software package 6.1 (Silicon Genetics, Redwood City, CA) were used to 
average results from different replicates and to perform statistical analysis to compare the sample groups. Differential gene expression between osteosarcoma and non-neoplastic osteoblasts was defined according to the following criteria: 1) upregulated genes are present in both replicates of osteosarcoma metastases and differential expression between conventional versus $\mathrm{HOBc}(>1.5)$ and metastases vs. $\mathrm{HOBc}(>1.5)$ is mandatory, 2) downregulated genes are present in both replicates of $\mathrm{HOBc}$ and a differential expression between conventional vs. $\mathrm{HOBc}(>1.5)$ and metastases vs. $\mathrm{HOBc}(>1.5)$ is mandatory. Expression levels below 1,000 were defined as background. The data were submitted to the GEO (Gene Expression Omnibus) database (GEO accession number GSE14359, geo@ncbi.nlm.nih.gov).

\section{Immunohistochemistry}

Immunohistochemical analyses were performed on paraffin-embedded tissues. As a nonneoplastic control, a tissue microarray (TMA) containing $n=4$ fetal and $n=6$ adult bone samples (each in duplicates; Provitro GmbH, Berlin, Germany) was used. Antigen retrieval was performed by incubation in trypsine (0.5\%, Zymed Digest-All Kit). To block endogenous peroxidase activity, peroxidase blocking reagent (DAKO) was used. The primary antibodies EFNA1, EFNA2, EFNB1, EFNB3 (all 1:10, Zymed) and EphA2 (1:10, Upstate) were incubated over night at $4^{\circ} \mathrm{C}$. The chromogene was 3, 3'-diaminobenzidine (DAB, DAKO) and nuclear counter staining was performed with hemalaun. All samples were semi-quantitatively scored by two different observers using a score modified according to Remmele and Stegner $^{13}$. 1. A score to measure the percentage of positively stained cells (PP) was performed as follows: $0=$ no staining, $1=1-25 \%, 2=26-50 \%, 3=51-75 \%, 4=76-100 \% .2$. A staining intensity score (SI) was established to measure the intensity of positively stained cells: $0=$ no expression, 1 = weak expression, 2 = moderate expression, $3=$ strong expression. The combined immunoreactivity score (IRS) value was calculated through PPxSI (maximum 
value was 12). Statistical analyses were performed executing the Mann-Whitney-U-Test and Bonferroni correction p-values using SPSS software 13.0. Differences were considered significant at $\mathrm{p}<0.05$.

\section{Immunoblot analysis}

Protein extracts were prepared by incubation with sodiumdodecylsulfate (SDS)-cell lysis buffer (10\% SDS, 1M TrisHCl pH 7.5, EDTA 0.5M pH8). Reagents for SDS-PAGE and Western blotting were obtained from Bio-Rad Laboratories (Richmond, CA). Electrophoresis was performed and proteins were transferred to nitrocellulose membranes (Schleicher \& Schüll). Membranes were blocked and specific proteins were detected by incubation with rabbit anti-human EFNA1 (V-18, 1:200 Santa Cruz), mouse anti-human EphA2 (Clone D7, 1:500 Upstate), mouse anti-human p-Tyr (1:1,000 Santa Cruz), rabbit anti-human P-Erk1/2 (p44/42 MAPK Thr202/Tyr204 1:1,000 Cell Signaling), mouse anti-human Erk1 (1:5,000 BD) and mouse anti-human actin (1:5,000 Chemicon) antibodies over night at $4^{\circ} \mathrm{C}$ following HRP-conjugated rabbit anti-mouse (1:5,000 Dianova) or goat anti-rabbit (1:2,000 Cell Signaling) secondary antibodies. Blots were developed using ECL system from Amersham. The quantification of blots was done using ImageJ.

\section{Immuofluorescence staining}

Cells were grown on glass slides and fixed with acetone. Immunofluorescence staining was performed using mouse anti-human EphA2 (Clone D7, 1:10 Upstate) antibody and visualized with Alexa488 (1:300 Invitrogen). Nuclei were counterstained with DAPI. Images were recorded using a fluorescence microscope (Zeiss). 


\section{Results}

\section{Expression of ephrins in osteosarcomas}

RNA derived from eight osteosarcoma samples ( $n=4$ conventional, $n=4$ metastases) and from the human osteoblast primary culture $\mathrm{HOBc}$ were analyzed using Affymetrix HG U133A microarrays. 1,163 genes were found significantly upregulated in conventional and metastatic osteosarcomas as compared to HOBc. 31 genes were expressed $>10$ fold in osteosarcomas compared to the non-neoplastic osteoblasts. Among them, EFNA1, a ligand for EphA tyrosine kinase receptors, was expressed $>10$ fold higher in osteosarcoma samples compared to osteoblasts (Tab. 2A). In addition, 2,059 genes were significantly downregulated between the osteosarcomas and HOBc. 37 genes were expressed less than 10 fold in osteosarcoma samples compared to osteoblasts (Tab. 2B).

During a recent study we discovered several ephrin genes deregulated in bone-related tumors, such as giant cell tumor of the bone ${ }^{5}$. For example, EFNA1 and EphA3 were upregulated in recurrent as compared to primary giant cell tumors, while EphAl and EphA4 were found downregulated in giant cell tumor recurrences. This prompted us to suggest that tissue-specific expression patterns of ephrins are associated with the development and progression of bone tumors. The observation that the EFNAl ligand light up as highly upregulated in the osteosarcoma samples versus non-neoplastic osteoblasts focused our further survey to the ephrin family and their expression in osteosarcoma tumor samples (Tab. 3). Within the 22,283 Affymetrix probe sets are five EFNA ligand probe sets (EFNA1-5), six EphA receptor probe sets (EphA1-5, EphA7), three EFNB ligand probe sets (EFNB1-3) and five EphB receptor probe sets (EphB1-4, EphB6).

EFNA1, EphA2 and EphA3 were found upregulated in osteosarcoma tissue compared to HOBc. No significant differences between conventional and metastases could be observed. EFNA4, EphA1, EphA4 and EphA5 were found to be expressed above background only in 1/8 osteosarcoma samples but below background in HOBc. Expression levels for EFNA2, 
EFNA3, EFNA5 and EphA7 were below background. Among the B-ligands, only EFNB2 showed a high expression in osteosarcomas and $\mathrm{HOBc}$, whereas expression below background was observed for EFNB1, EFNB3 and EphB1. For the B-class receptors EphB2, EphB3 (6/8 osteosarcoma samples), EphB4 and EphB6 (5/8 osteosarcoma samples) an expression level above background in osteosarcomas, but no differential expression was detected. With the exception of EphB4, ephrinB receptor expression in HOBc was below background.

\section{Ephrin proteins are expressed at elevated levels in osteosarcomas}

To confirm the differential expression of ephrins at the protein level, we stained osteosarcoma tissue samples ( $n=10$ primary tumors and $n=7$ metastases) using anti-EFNA1, anti-EFNA2, anti-EFNB1, anti-EFNB3 and anti-EphA2-specific antibodies. For EFNA1, EFNB1 and EphA2 a tissue microarray harboring several non-neoplastic human bone samples $(n=18)$ were stained in addition. The immunoreactive scores for all antigens are shown in Tab. 4.

\section{EFNA1 protein levels are increased in osteosarcomas}

As already suggested from the microarray analysis, a significant upregulation of EFNA1 was detected in osteosarcomas compared to non-neoplastic bone $(\mathrm{p}=0.0003)$. EFNA1 expression was observed in 7 out of 8 cases of both fetal and adult osteocytes, in osteoblasts and in osteoclasts of non-neoplastic bone (Fig. 1A), but no significant differences between fetal and normal adult bone were found $(\mathrm{p}=0.33)$. However, EFNA1 was detectable at higher intensities in all osteosarcoma samples, where nearly $80 \%$ of tumor cells stained positive (Fig. 1B), yet no significant differences between conventional osteosarcomas and metastases were found $(\mathrm{p}=1)$. The EFNA1 immunoreactivity was localized to the membrane and to the cytoplasm of the tumor cells. Interestingly, five osteosarcoma samples showed a nuclear EFNA1 expression (Fig. 1C). 


\section{EphA2 protein is expressed de novo in osteosarcomas}

In contrast to the EFNA1 ligand, the EphA2 receptor was not present in fetal and adult nonneoplastic bone (Fig. 1D), but 13/17 osteosarcoma samples showed expression of the EphA2 receptor (Fig. 1E, F). The EphA2 immunoreactivity was largely confined to tumor cells around the bone formations (Fig. 1E arrow). Again, a significant upregulation of EphA2 in osteosarcomas compared to non-neoplastic bone could be confirmed at the protein level $(\mathrm{p}=0.000024)$, no significant differences between conventional osteosarcomas and metastases were found $(\mathrm{p}=1)$.

\section{Differential expression of EFNB1, EFNA2 and EFNB3}

4/8 fetal bone samples showed a cytoplasmic expression of EFNB1 (Fig. 2A), while no EFNB1 protein was found in the adult bone (Fig. 2B). The EFNB1 immunoreactivity was largely confined to the osteoblasts of fetal bone and to the tumor cells around the bone formations. In contrast to adult bone, all osteosarcoma tissue samples showed an EFNB1 protein expression (Fig. 2C, D). A significant upregulation of EFNB1 in osteosarcomas compared to non-neoplastic bone could be confirmed at the protein level $(\mathrm{p}=0.000054)$. Like EphA2 receptor, the EFNB1 ligand appeared de novo expressed in osteosarcoma primary tumors, but was significantly downregulated in the metastases as compared to conventional osteosarcomas ( $\mathrm{p}=0.015)$. EFNA2 (Fig. 3A, B) and EFNB3 (Fig. 3C, D) showed no significant differences between conventional osteosarcomas and metastases $(p=0.3$ and $p=1$, respectively). The EFNA2, EFNB1 and EFNB3 immunoreactivity was localized to the cytoplasm of the tumor cells. Interestingly, an expression of EFNA2 and EFNB3 was also found in the endothelial cells of tumor blood vessels (Fig. 2B, D arrows).

\section{EFNA1-mediated EphA2 receptor phosphorylation and internalization}

The deregulation of EFNA1 or EphA2 and the EFNA1-EphA2 ligand-receptor signaling plays an important role in tumor development and metastasis in several carcinomas. To investigate 
the potential of ephrin signaling in osteosarcomas, we further analyzed EFNA1 and EphA2 expression and regulation in vitro. Osteosarcoma cell lines were tested for their EFNA1 and EphA2 protein expression. Using Western blot, different levels of EFNA1 ligand and EphA2 receptor protein could be detected in the cell lines (Fig. 4A). SaOS2 expressed the highest level of EphA2, while only a weak EphA2 expression could be observed in HOBc. EFNA1 was detected at nearly similar levels in all cell lines, with slightly lower levels in ZK58, $\mathrm{SaOS} 2$ and HOBc.

EFNA1-mediated aggregation of EphA2 receptors stimulates receptor internalization and degradation in breast and prostate carcinomas ${ }^{14,15}$. Because of the high EphA2-expression in SaOS2 and MNNG/HOS, these cell lines were used for further analysis. The EphA2 subcellular localization without addition of the soluble ligand revealed a membranous expression at the sites of SaOS2 cell-cell contact and enrichment within membrane ruffles (Fig. 4B). In MNNG/HOS cells, EphA2 was mainly concentrated at sites of cell-cell contact (Fig. 4C). Analysis of EphA2 localization following the addition of EFNA1/ $F_{c}$ revealed a redistribution of the EphA2 receptor from the plasma membrane within 10min after treatment of SaOS2 and MNNG/HOS cells (Fig. 4B, C). EphA2 immunoreactivity as measured by Western blot decreased within one hour following Ephrin $\mathrm{A} 1 / \mathrm{F}_{\mathrm{c}}$ exposures and $70-90 \%$ of the EphA2-protein was lost after 2h in SaOS2 and MNNG/HOS cells (Fig. 5A, B).

EphA2 is enriched at cell-cell contacts in non-transformed epithelial cells where it binds the ligand and becomes phosphorylated ${ }^{16}$. In carcinoma cells, EphA2 often remains non-phosphorylated because overexpression is accompanied by an altered EphA2 localization resulting in a failure to bind the EFNA1 ligand ${ }^{16}$. However, unlike other tyrosine receptor kinases, EphA2 receptors have a kinase activity independent of phosphorylation and are even assumed to participate in prostate cancer metastasis ${ }^{11,16}$. In SaOS2 and MNNG/HOS cells the EphA2 receptor is overexpressed and localized in membrane ruffles and at cell-cell-contacts. We aimed to determine whether EphA2 receptors are potentially phosphorylated in the 
presence of the EFNA1/ $\mathrm{F}_{\mathrm{c}}$ soluble ligand, because we showed that both ligand and receptor are present in osteosarcomas. In both osteosarcoma cell lines, an increase in phospho-tyrosine protein level was detectable 2 min after binding of the soluble ligand (Fig. 5A, B). After two hours, only weak phosphorylation could be detected, which was consistent with the internalization of the EphA2 receptor following ligand binding. These results suggested that in osteosarcoma cells the interaction between EphA2 receptor and EFNA1 ligand, both overexpressed in tumor samples, might result in phosphorylation and activation of the EphA2 receptor.

\section{EFNA1-ligand binding to the $\operatorname{EphA2}$ receptor induces activation of MAPK signaling}

Previous reports suggested that in breast and prostate carcinoma cells ephrin receptor-ligand interaction results in receptor phosphorylation and downregulation of phospho-Erk1/2 levels through a negative feedback-loop ${ }^{14}$. In contrast, Pratt et al. 2002 found an increased Erk1/2 activity after treatment with EFNA1/ $F_{c}$ in MDA-MB-231 breast cancer cells ${ }^{15}$. To determine the effects of EphA receptor activation following ligand application in osteosarcomas, we assessed Ras-MAPK-signaling through Western blot analysis following EFNA1/ $\mathrm{F}_{\mathrm{c}}$ ligand binding. In SaOS2 and MNNG/HOS cells Erk1/2 phosphorylation increased within 2min after EFNA1 ligand treatment, peaked at $2 \mathrm{~h}$ and $30 \mathrm{~min}$, respectively and then slowly declined (Fig. 5A, B). These data clearly demonstrate that elevated levels of both EFNA1 ligand and EphA2 receptor in osteosarcomas are likely to contribute to an increased mitogenic signaling via the Ras-MAPK pathway.

\section{EFNA1-EphA2 signaling enhances cell migration in osteosarcoma cells}

Previous reports have suggested an involvement of the EphA receptor class in breast cancer cell migration and invasion ${ }^{17}$. Therefore we tested the effect of EphA2 activation by EFNA1/ $\mathrm{F}_{\mathrm{c}}$ on anchorage-independent and anchorage-dependent growth and migration of 
EphA2-expressing cells. MNNG/HOS cells were treated with $1 \mu \mathrm{g} / \mathrm{ml}$ EFNA1/F $\mathrm{F}_{\mathrm{c}}$ for $96 \mathrm{~h}$ and cell growth was analyzed. MNNG/HOS cells showed a small increase in growth on plastic 96h after EFNA1/ $/ \mathrm{F}_{\mathrm{c}}$-treatment (Fig. 6A). In addition, MNNG/HOS cells also showed a 20\% increase in anchorage-independent growth, suggesting a limited growth stimulatory role of EFNA1-EphA2 signaling (Fig. 6B). For migration studies, MNNG/HOS cells were treated with $1 \mu \mathrm{g} / \mathrm{ml}$ EFNA1/F $\mathrm{F}_{\mathrm{c}}$ up to $48 \mathrm{~h}$ (Fig. 6C). A slight increase in migration using the soluble ligand compared to untreated cells was observed after $24 \mathrm{~h}$ and $48 \mathrm{~h}$.

\section{EFNA1/F $F_{c}$ mediated stimulation of EphA2 induces autoregulation of EphA2 and EFNA1}

Earlier investigations had suggested that EphA2 expression can be stimulated via EGFR and the downstream Mek/Erk signaling in the human epidermal carcinoma cell line A431 and in the head and neck carcinoma cell line $\mathrm{HN} 5^{18}$. Our investigations in osteosarcoma cells now revealed a role for the EphA2 receptor itself in the activation of this pathway. Therefore we investigated whether the EphA2 and EFNA1 genes might exert an autoregulation following EFNA1 ligand binding. Treatment of MNNG/HOS cells with the ligand induced EFNAI mRNA after $5 \mathrm{~min}$ and the elevated levels persisted up to $48 \mathrm{~h}$ (Fig. 7A). EphA2 mRNA showed a slight upregulation after $1 \mathrm{~h}$ in MNNG/HOS cells, however overall the induction was weak (Fig. 7A). These results indicate a potential autoregulatory loop, which increases mainly EFNA1 mRNA levels in osteosarcoma cells upon ligand binding. To define to what extent the EFNA1 and EphA2 autoregulation was MAPK-dependent we treated MNNG/HOS cells with the Mek-inhibitor U0126 and measured protein and mRNA expression of EphA2 and EFNA1 by Western blot and RT-PCR, respectively. Both EphA2 and EFNA1 protein and mRNA were reduced through treatment with U0126 (Fig. 7B). 


\section{Discussion}

Today, a number of molecular markers have been identified in osteosarcomas, some of which have the potential to act as novel therapeutic targets ${ }^{19}$. For example VEGF expression in osteosarcoma correlates with the level of microvascular density and the presence of pulmonary metastases ${ }^{20}$. In addition, increased levels of MMP9 are associated with increased metastatic potential and the receptor tyrosine kinases ErbB2/Her-2 and c-Met are overexpressed and/or amplified in bone tumors ${ }^{21-23}$. Current treatment procedures involve surgical resection and neoadjuvant chemotherapy involving methotrexate, cisplatin, and adriamycin and have resulted in tumor-type dependent response rates up to $80 \%$. Nevertheless, a significant fraction of patients (app. 30\%) die because of metastases. Therefore, an improved understanding of the molecular mechanisms driving osteosarcoma progression and metastasis and the establishment of novel diagnostic and therapeutic targets is urgently needed.

Using microarray analysis, we detected a distinct expression profile for several ephrins and their receptors in human osteosarcoma tissue samples when compared to non-neoplastic human bone. The Ephrin receptors and ligands are associated with tumor development, progression and metastasis in numerous human cancers. The EphA2 receptor is upregulated in colorectal, lung and breast cancer, as well as in melanomas and is often found to correlate with tumor stage ${ }^{24}$. Several publications described a role in angiogenesis, migration and tumor compartimentalization $^{25,26}$. However, a functional diversity was observed within the ephrin family. For example, an oncogenic role was found for the EphA/EFNA ligand-receptor system but a tumor suppressive role for EphB receptors ${ }^{27,}{ }^{28}$. In osteosarcoma, ephrin expression was first described by Varelias et al. (2002), who found distinct expression profiles for several ephrins within tumor samples and osteosarcoma cell lines ${ }^{6}$. Using microarray analysis and immunohistochemistry we extended these data and confirmed high overexpression of the EphA2 receptor and the EFNA1 ligand in the majority of human 
osteosarcomas. While the ligand was also detected in fetal and adult normal tissue but strongly upregulated in tumor tissue, de novo expression was detected for the EphA2 receptor in tumor tissue. This indicates that during osteosarcoma development a potential change in ligand-receptor interaction within the A-class of ephrins might occur. The EFNA1 ligand is able to bind the EphA2 receptor with high affinity ${ }^{29}$, yet binds also other members of the Aclass receptors. Absence of EphA2 from fetal and adult normal human bone, but a strong upregulation during tumor development suggests a specific role for the EFNA1 ligand-EphA2 receptor interaction in osteosarcoma. Our microarray data also imply upregulation of the EphA3 receptor in osteosarcomas. This suggests that EFNA1 might also interact with this receptor, however at the moment an involvement of EphA3 in osteosarcoma is unknown.

In cells derived from breast cancer and other carcinomas, controversial results were also reported with respect to signaling cascade activation upon EFNA1-mediated EphA2 stimulation. Macrae et al. found a negative feedback loop involving transcriptional regulation of EphA2 and suppression of Ras function ${ }^{14}$, also Wykosky et al. recently suggested that soluble EFNA1 upon interaction with EphA2 suppresses Ras/MAPK signaling in cells derived from glioblastoma multiforme ${ }^{30}$. In contrast, others suggested activation of MAPK signaling through the EFNA1 ligand ${ }^{15}$. Stimulation of osteosarcoma cells with the soluble EFNA1 ligand induced MAPK signaling as indicated by Erk1/2 phosphorylation. Activation of MAPK signaling and the control of downstream effectors such as Fos and Jun have key cellular functions such as proliferation and migration and are linked to osteosarcoma development ${ }^{31}$. In contrast to the data described in breast and also in prostate cancer cells, applications of the EFNA1 ligand to MNNG/HOS cells induced migration and to a lower extend also proliferation. This observation indicates that EFNA1 EphA2 upregulation in osteosarcoma might be positively involved in the known oncogenic pathways responsible for osteosarcoma formation and progression. Interestingly our data also suggest a positive feedback loop including the EFNA1 EphA2 ligand-receptor system and acting via 
-16 -

Ras/MAPK. In prostate cancer cells the EFNA1 ligand induces dephosphorylation of focal adhesion kinase (FAK) followed by inhibition of cell spreading and migration ${ }^{32}$. Parri et al. 2005 extended these findings and demonstrated a repulsive response of PC3 prostate cancer cells following EFNA1 application; however in the absence of FAK dephosphorylation ${ }^{33}$. These observations are in line with our data indicating a migratory response of osteosarcoma cells in vitro. We were however unable to detect FAK dephosphorylation following EFNA1 application (data not shown). Thus it remains to be determined to what extend FAK is involved in EFNA1-induced migration of osteosarcoma cells and suggests a totally different role in growth and migration control of EFNA1 ligand-EphA2 receptor interaction in bone tumors as compared to epithelial tumors.

The strong upregulation of EFNA1 ligand and EphA2 receptor in osteosarcomas marks the ephrins as interesting potential therapeutic target. Noberini et al (2008) showed, that small molecules are able to selectively inhibit the interaction of EphA2 with its natural ligand $^{34}$. These compounds also inhibit ephrin-induced phosphorylation of EphA2 without affecting cell viability or the phosphorylation of other receptor tyrosine kinases. Thus, further analysis on the role of EFNA1 and EphA2 in osteosarcomas might determine whether EphA2 is a possible therapeutic target for the treatment with small inhibitory molecules in osteosarcoma patients. 


\section{References}

1. Campanacci M. Bone Tumors. Lippincott-Verlag 1999;1418-1468.

2. Gelberg KH, Fitzgerald EF, Hwang S, Dubrow R. Growth and development and other risk factors for osteosarcoma in children and young adults. Int J Epidemiol 1997;26;272-278.

3. Friedman MA, Carter SK. The therapy of osteogenic sarcoma: current status and thoughts for the future. J Surg Oncol 1972;4;482-510.

4. Arndt CA, Crist WM. Common musculoskeletal tumors of childhood and adolescence. N Engl J Med 1999;341;342-352.

5. Guenther R, Krenn V, Morawietz L et al. Giant cell tumors of the bone: molecular profiling and expression analysis of Ephrin A1 receptor, Claudin 7, CD52, FGFR3 and AMFR. Pathol Res Pract 2005;201;649-663.

6. Varelias A, Koblar SA, Cowled PA, Carter CD, Clayer M. Human osteosarcoma expresses specific ephrin profiles: implications for tumorigenicity and prognosis. Cancer $2002 ; 95 ; 862-869$.

7. Parri M, Taddei ML, Bianchini F, Calorini L, Chiarugi P. EphA2 reexpression prompts invasion of melanoma cells shifting from mesenchymal to amoeboid-like motility style. Cancer research 2009;69;2072-2081.

8. Surawska H, Ma PC, Salgia R. The role of ephrins and Eph receptors in cancer. Cytokine Growth Factor Rev 2004;15;419-433.

9. Dong Y, Wang J, Sheng Z et al. Downregulation of EphA1 in colorectal carcinomas correlates with invasion and metastasis. Mod Pathol 2009;22;151-160.

10. Herath NI, Doecke J, Spanevello MD, Leggett BA, Boyd AW. Epigenetic silencing of EphA1 expression in colorectal cancer is correlated with poor survival. British journal of cancer 2009;100;1095-1102. 
11. Taddei ML, Parri M, Angelucci A et al. Kinase-dependent and -independent roles of EphA2 in the regulation of prostate cancer invasion and metastasis. The American journal of pathology 2009;174;1492-1503.

12. Oike $\mathrm{Y}$, Ito $\mathrm{Y}$, Hamada $\mathrm{K}$ et al. Regulation of vasculogenesis and angiogenesis by EphB/ephrin-B2 signaling between endothelial cells and surrounding mesenchymal cells. Blood 2002;100;1326-1333.

13. Remmele W, Stegner H. Recommendation for uniform definition of an immunoreactive score (IRS) for immunohistochemical estrogen receptor detection (ER-ICA) in breast cancer tissue. Pathologe 1987;8;138-140.

14. Macrae M, Neve RM, Rodriguez-Viciana $\mathrm{P}$ et al. A conditional feedback loop regulates Ras activity through EphA2. Cancer cell 2005;8;111-118.

15. Pratt RL, Kinch MS. Activation of the EphA2 tyrosine kinase stimulates the MAP/ERK kinase signaling cascade. Oncogene 2002;21;7690-7699.

16. Zantek ND, Azimi M, Fedor-Chaiken M, Wang B, Brackenbury R, Kinch MS. Ecadherin regulates the function of the EphA2 receptor tyrosine kinase. Cell Growth Differ $1999 ; 10 ; 629-638$.

17. Fang WB, Brantley-Sieders DM, Parker MA, Reith AD, Chen J. A kinase-dependent role for EphA2 receptor in promoting tumor growth and metastasis. Oncogene 2005;24;78597868.

18. Larsen AB, Pedersen MW, Stockhausen MT, Grandal MV, van Deurs B, Poulsen HS. Activation of the EGFR gene target EphA2 inhibits epidermal growth factor-induced cancer cell motility. Mol Cancer Res 2007;5;283-293.

19. Clark JC, Dass CR, Choong PF. A review of clinical and molecular prognostic factors in osteosarcoma. Journal of cancer research and clinical oncology 2008;134;281-297. 
20. Kaya M, Wada T, Akatsuka $\mathrm{T}$ et al. Vascular endothelial growth factor expression in untreated osteosarcoma is predictive of pulmonary metastasis and poor prognosis. Clin Cancer Res 2000;6;572-577.

21. Onda M, Matsuda S, Higaki S et al. ErbB-2 expression is correlated with poor prognosis for patients with osteosarcoma. Cancer 1996;77;71-78.

22. Coltella N, Manara MC, Cerisano V et al. Role of the MET/HGF receptor in proliferation and invasive behavior of osteosarcoma. Faseb $J$ 2003;17;1162-1164.

23. Kido A, Tsutsumi M, Iki K et al. Overexpression of matrix metalloproteinase (MMP)9 correlates with metastatic potency of spontaneous and 4-hydroxyaminoquinoline 1-oxide (4HAQO)-induced transplantable osteosarcomas in rats. Cancer letters 1999;137;209-216.

24. Saito $\mathrm{T}$, Masuda N, Miyazaki $\mathrm{T}$ et al. Expression of EphA2 and E-cadherin in colorectal cancer: correlation with cancer metastasis. Oncol Rep 2004;11;605-611.

25. Brantley DM, Cheng N, Thompson EJ et al. Soluble Eph A receptors inhibit tumor angiogenesis and progression in vivo. Oncogene 2002;21;7011-7026.

26. Brantley-Sieders DM, Caughron J, Hicks D, Pozzi A, Ruiz JC, Chen J. EphA2 receptor tyrosine kinase regulates endothelial cell migration and vascular assembly through phosphoinositide 3-kinase-mediated Rac1 GTPase activation. Journal of cell science 2004;117;2037-2049.

27. Batlle E, Bacani J, Begthel $\mathrm{H}$ et al. EphB receptor activity suppresses colorectal cancer progression. Nature 2005;435;1126-1130.

28. Noren NK, Pasquale EB. Paradoxes of the EphB4 receptor in cancer. Cancer research 2007;67;3994-3997.

29. Bartley TD, Hunt RW, Welcher AA et al. B61 is a ligand for the ECK receptor protein-tyrosine kinase. Nature 1994;368;558-560. 
30. Wykosky J, Palma E, Gibo DM, Ringler S, Turner CP, Debinski W. Soluble monomeric EphrinA1 is released from tumor cells and is a functional ligand for the EphA2 receptor. Oncogene 2008;27;7260-7273.

31. Wagner EF, Eferl R. Fos/AP-1 proteins in bone and the immune system. Immunol Rev 2005;208;126-140.

32. Miao H, Burnett E, Kinch M, Simon E, Wang B. Activation of EphA2 kinase suppresses integrin function and causes focal-adhesion-kinase dephosphorylation. Nature cell biology 2000;2;62-69.

33. Parri M, Buricchi F, Taddei ML et al. EphrinA1 repulsive response is regulated by an EphA2 tyrosine phosphatase. J Biol Chem 2005;280;34008-34018.

34. Noberini R, Koolpe M, Peddibhotla S et al. Small molecules can selectively inhibit ephrin binding to the EphA4 and EphA2 receptors. J Biol Chem 2008;283;29461-29472. 


\begin{abstract}
Aknowledgement
This study was supported by the national genome research network (Nationales Genomforschungsnetz, NGFN, SIPAGE) and by the German Federal Ministry of Education and Research (BMBF) through the program FORSYS Partner (grant 0315261).
\end{abstract}




\section{Tables}

Table 1: Tissue from patients with osteosarcoma used for microarray and immunohistochemical analyses. * used for microarray and immunohistochemical analyses. + : not used for immunohistochemical staining. $\mathrm{f}=$ female. $\mathrm{m}=$ male.

\begin{tabular}{|l|l|l|l|l|}
\hline Number & \multicolumn{1}{|c|}{ Type } & Sex & Age & Localization \\
\hline OS1* & conventional & $\mathrm{f}$ & 15 & Femur \\
\hline OS2 & conventional & $\mathrm{m}$ & 16 & Tibia \\
\hline OS3 & conventional & $\mathrm{m}$ & 74 & Humerus \\
\hline OS4* & metastasis & $\mathrm{m}$ & 40 & Lung \\
\hline OS5 & metastasis & $\mathrm{m}$ & 59 & Lung \\
\hline OS6* & metastasis & $\mathrm{f}$ & 21 & Lung \\
\hline OS7 & metastasis & $\mathrm{f}$ & 20 & Lung \\
\hline OS9* & conventional & $\mathrm{m}$ & 23 & Tibia \\
\hline OS10 & metastasis & $\mathrm{m}$ & 24 & Lung \\
\hline OS11 & metastasis & $\mathrm{f}$ & 45 & Lung \\
\hline OS12* & metastasis & $\mathrm{m}$ & 67 & Lung \\
\hline OS14 & conventional & $\mathrm{m}$ & 56 & Scapula \\
\hline OS15* & conventional & $\mathrm{f}$ & 74 & Femur \\
\hline OS16* & conventional & $\mathrm{f}$ & 37 & Lung \\
\hline OS17 & conventional & $\mathrm{m}$ & 54 & Tibia \\
\hline OS18* & conventional & $\mathrm{m}$ & 7 & Femur \\
\hline OS20 & conventional & $\mathrm{m}$ & 33 & Femur \\
\hline OS21 & conventional & $\mathrm{m}$ & 59 & Femur \\
\hline OS24* & conventional & $\mathrm{m}$ & 17 & Femur \\
\hline
\end{tabular}


Table 2: Genes with at least 10 fold overexpression (A) or suppression (B) in osteosarcoma compared to HOBc. Fc: fold change. ID: Affymetrix identity.

\section{A: Genes with at least 10 fold overexpression in osteosarcomas compared to HOBc}

\begin{tabular}{|c|c|c|c|}
\hline ID & Symbol & fc & Gene \\
\hline 207370_at & IBSP & 41.7 & integrin-binding sialoprotein \\
\hline 201721_s_at & LAPTM5 & 29.8 & lysosomal multispanning membrane protein 5 \\
\hline 218678_at & NES & 28.7 & nestin \\
\hline 217028_at & CXCR4 & 25.7 & chemokine (C-X-C motif) receptor 4 \\
\hline 201720_s_at & LAPTM5 & 23.4 & lysosomal multispanning membrane protein 5 \\
\hline 204712_at & WIF1 & 22.2 & Wnt inhibitory factor-1 \\
\hline 203305_at & F13A1 & 20.6 & coagulation factor XIII, A1 polypeptide \\
\hline 213068_at & DPT & 19.6 & dermatopontin \\
\hline 215049_x_at & CD163 & 19.0 & CD163 molecule \\
\hline 201117_s_at & $\mathrm{CPE}$ & 18.6 & carboxypeptidase $\mathrm{E}$ \\
\hline 204379_s_at & FGFR3 & 17.8 & fibroblast growth factor receptor 3 \\
\hline 201116_s_at & $\mathrm{CPE}$ & 17.5 & carboxypeptidase $\mathrm{E}$ \\
\hline 202878_s_at & CD93 & 15.9 & Complement component $1, \mathrm{q}$ subcomponent, receptor 1 \\
\hline 207977_s_at & DPT & 15.8 & dermatopontin \\
\hline 215783_s_at & ALPL & 14.5 & alkaline phosphatase, liver/bone/kidney \\
\hline 217897_at & FXYD6 & 14.5 & FXYD domain containing ion transport regulator 6 \\
\hline 206488_s_at & CD36 & 13.7 & CD36 molecule (thrombospondin receptor) \\
\hline 203645_s_at & CD163 & 13.6 & CD163 molecule \\
\hline 221558_s_at & LEF1 & 13.5 & lymphoid enhancer-binding factor 1 \\
\hline 218002_s_at & CXCL14 & 13.4 & chemokine (C-X-C motif) ligand 14 \\
\hline 202023_at & EFNA1 & 13.0 & ephrin-A1 \\
\hline
\end{tabular}




\begin{tabular}{|l|c|c|l|}
\hline 209087_x_at & MCAM & 12.2 & melanoma cell adhesion molecule \\
\hline 219478_at & WFDC1 & 12.1 & WAP four-disulfide core domain 1 \\
\hline 266_s_at & CD24 & 12.0 & CD24 molecule \\
\hline 202746_at & ITM2A & 11.4 & integral membrane protein 2A \\
\hline 208146_s_at & CPVL & 11.1 & carboxypeptidase, vitellogenic-like \\
\hline 219607_s_at & MS4A4A & 11.0 & membrane-spanning 4-domains, subfamily A, member 4 \\
\hline 211343_s_at & COL13A1 & 10.7 & collagen, type XIII, alpha 1 \\
\hline 202747_s_at & ITM2A & 10.6 & integral membrane protein 2A \\
\hline 214574_x_at & LST1 & 10.2 & leukocyte specific transcript 1 \\
\hline 209301_at & CA2 & 10.1 & carbonic anhydrase II \\
\hline
\end{tabular}




\section{B: Genes with at least 10 fold suppression in osteosarcomas compared to HOBc}

\begin{tabular}{|c|c|c|c|}
\hline ID & Symbol & fc & Gene \\
\hline 209395_at & CHI3L1 & 123.9 & chitinase 3-like 1 (cartilage glycoprotein-39) \\
\hline 209396_s_at & CHI3L1 & 87.0 & chitinase 3-like 1 (cartilage glycoprotein-39) \\
\hline 205792_at & WISP2 & 65.4 & WNT1 inducible signaling pathway protein 2 \\
\hline 203851_at & IGFBP6 & 37.6 & insulin-like growth factor binding protein 6 \\
\hline 218468_s_at & GREM1 & 31.8 & $\begin{array}{l}\text { gremlin 1, cysteine knot superfamily, homolog } \\
\text { (Xenopus laevis) }\end{array}$ \\
\hline 204948_s_at & FST & 27.2 & follistatin \\
\hline 212143_s_at & IGFBP3 & 23.3 & insulin-like growth factor binding protein 3 \\
\hline 206157_at & PTX3 & 22.6 & pentraxin-related gene, rapidly induced by IL-1 beta \\
\hline 201107_s_at & THBS1 & 21.6 & thrombospondin 1 \\
\hline 209355_s_at & PPAP2B & 20.3 & phosphatidic acid phosphatase type $2 \mathrm{~B}$ \\
\hline 203963_at & CA12 & 20.0 & carbonic anhydrase XII \\
\hline 202949_s_at & FHL2 & 19.4 & four and a half LIM domains 2 \\
\hline 204508_s_at & CA12 & 18.2 & carbonic anhydrase XII \\
\hline 202912_at & ADM & 18.0 & adrenomedullin \\
\hline 209687_at & CXCL12 & 17.6 & $\begin{array}{l}\text { chemokine (C-X-C motif) ligand } 12 \text { (stromal cell- } \\
\text { derived factor } 1)\end{array}$ \\
\hline 205475_at & SCRG1 & 16.6 & scrapie responsive protein 1 \\
\hline 206172_at & IL13RA2 & 16.0 & interleukin 13 receptor, alpha 2 \\
\hline 201108_s_at & THBS1 & 15.2 & thrombospondin 1 \\
\hline 213112_s_at & SQSTM1 & 14.2 & sequestosome 1 \\
\hline 203939_at & NT5E & 13.4 & 5'-nucleotidase, ecto (CD73) \\
\hline 212226_s_at & PPAP2B & 12.9 & phosphatidic acid phosphatase type $2 \mathrm{~B}$ \\
\hline
\end{tabular}




\begin{tabular}{|l|l|l|l|}
\hline 201109_s_at & THBS1 & 12.7 & thrombospondin 1 \\
\hline 212344_at & SULF1 & 12.6 & sulfatase 1 \\
\hline 214767_s_at & HSPB6 & 12.3 & heat shock protein, alpha-crystallin-related, B6 \\
\hline 205397_x_at & SMAD3 & 12.2 & SMAD family member 3 \\
\hline 212230_at & PPAP2B & 12.1 & phosphatidic acid phosphatase type 2B \\
\hline 202275_at & G6PD & 12.0 & glucose-6-phosphate dehydrogenase \\
\hline 208502_s_at & PITX1 & 11.7 & paired-like homeodomain 1 \\
\hline 221111_at & IL26 & 11.4 & interleukin 26 \\
\hline 202434_s_at & CYP1B1 & 11.3 & cytochrome P450, family 1, subfamily B, polypeptide 1 \\
\hline 202436_s_at & CYP1B1 & 11.3 & cytochrome P450, family 1, subfamily B, polypeptide 1 \\
\hline 212992_at & AHNAK2 & 11.2 & AHNAK nucleoprotein 2 \\
\hline 204037_at & LPAR1 & 11.0 & lysophosphatidic acid receptor 1 \\
\hline 207345_at & FST & 10.9 & follistatin \\
\hline 202765_s_at & FBN1 & 10.5 & fibrillin 1 \\
\hline 205924_at & RAB3B & 10.3 & RAB3B, member RAS oncogene family \\
\hline
\end{tabular}


Table 3: Ephrin expression profile in osteosarcoma tissue samples compared to the non neoplastic osteoblast primary culture HOBc. Relative expression levels below 1,000 were defined as background. OS: osteosarcoma.

\begin{tabular}{|c|c|c|c|c|}
\hline $\begin{array}{c}\text { Relative } \\
\text { Expression }\end{array}$ & A-Ligand & A-Receptor & B-Ligand & B-Receptor \\
\hline $\begin{array}{l}\text { significant } \\
(>1,000)\end{array}$ & $\begin{array}{l}\text { EFNA1 } \\
\text { (HOBc below 1,000, 8/8 } \\
\text { OS above 1,000) } \\
\text { EFNA4 } \\
\text { (1/8 OS above 1,000, } \\
\text { HOBc below } 1,000)\end{array}$ & $\begin{array}{l}\text { EphA1 } \\
\text { (1/8 OS above 1000, } \\
\text { HOBc below 1,000) } \\
\text { EphA2 } \\
\text { (all probes above 1,000) } \\
\text { EphA3 } \\
\text { (HOBc and 1/8 OS below } \\
\text { 1,000) } \\
\text { EphA4 } \\
\text { (1/8 OS above 1,000, } \\
\text { HOBc below 1,000) } \\
\text { EphA5 } \\
\text { (1/8 OS above 1000, } \\
\text { HOBc below 1,000) }\end{array}$ & $\begin{array}{l}\text { EFNB2 } \\
\text { (all probes above 1,000) }\end{array}$ & $\begin{array}{l}\text { EphB2 } \\
\text { (HOBc below 1,000, 8/8 } \\
\text { OS above 1,000) } \\
\text { EphB3 } \\
\text { (HOBc and 2/8 OS below } \\
\text { 1000) } \\
\text { EphB4 } \\
\text { (all probes above 1,000) } \\
\text { EphB6 } \\
\text { (5/8 OS above 1,000) }\end{array}$ \\
\hline $\begin{array}{c}\text { not } \\
\text { significant } \\
(<1,000)\end{array}$ & $\begin{array}{l}\text { EFNA2 } \\
\text { (all probes below 1,000) } \\
\text { EFNA3 } \\
\text { (all probes below 1,000) } \\
\text { EFNA5 } \\
\text { (all probes below 1,000) }\end{array}$ & $\begin{array}{l}\text { EphA7 } \\
\text { (all probes below 1,000) }\end{array}$ & $\begin{array}{l}\text { EFNB1 } \\
\text { (all probes below 1,000) } \\
\text { EFNB3 } \\
\text { (all probes below 1,000) }\end{array}$ & $\begin{array}{l}\text { EphB1 } \\
\text { (all probes below 1,000) }\end{array}$ \\
\hline
\end{tabular}


Table 4: Immunohistochemical analyses of EFNA1, EFNA2, EFNB1, EFNB3 and EphA2 in human osteosarcoma and non-neoplastic bone tissue samples. The immunohistochemical staining was calculated through the immunoreactive score (IRS) of the whole tissue sample. PP: percentage of positively stained cells. SI: intensity of positively stained cells.

\begin{tabular}{|c|c|c|c|c|c|c|c|}
\hline & \multicolumn{3}{|c|}{ Osteosarcoma } & \multicolumn{3}{|c|}{ Bone } \\
\hline & & Conventional & Metastases & Total & Fetal & Adult & Total \\
\hline \multirow{3}{*}{$\begin{array}{l}\text { EFNA1 } \\
\text { ligand }\end{array}$} & SI & 2.6 & 2.6 & 2.6 & 0.9 & 1.9 & 1.5 \\
\hline & PP & 3.8 & 3.3 & 3.6 & 1.3 & 2.4 & 1.9 \\
\hline & IRS & 10.1 & 9.1 & 9.7 & 2.6 & 4.7 & 3.8 \\
\hline \multirow{3}{*}{$\begin{array}{c}\text { EFNA2 } \\
\text { ligand }\end{array}$} & SI & 2.1 & 2.1 & 2.1 & & & \\
\hline & PP & 3.3 & 2.9 & 3.1 & & & \\
\hline & IRS & 7.9 & 6.1 & 7.2 & & & \\
\hline \multirow{3}{*}{$\begin{array}{l}\text { EFNB1 } \\
\text { ligand }\end{array}$} & SI & 2.7 & 1.9 & 2.4 & 1.6 & 0.0 & 0.7 \\
\hline & $\mathbf{P P}$ & 3.0 & 2.1 & 2.6 & 1.0 & 0.0 & 0.4 \\
\hline & IRS & 8.1 & 4.3 & 6.5 & 3.3 & 0.0 & 1.4 \\
\hline \multirow{3}{*}{$\begin{array}{l}\text { EFNB3 } \\
\text { ligand }\end{array}$} & SI & 2.0 & 2.0 & 2.0 & \multirow{3}{*}{\multicolumn{3}{|c|}{$(8)$}} \\
\hline & $\mathbf{P P}$ & 3.0 & 2.4 & 2.8 & & & \\
\hline & IRS & 6.9 & 5.7 & 6.4 & & & \\
\hline \multirow{3}{*}{$\begin{array}{l}\text { EphA2 } \\
\text { receptor }\end{array}$} & SI & 1.0 & 1.3 & 1.1 & 0.0 & 0.0 & 0.0 \\
\hline & PP & 1.8 & 1.3 & 1.6 & 0.0 & 0.0 & $\mathbf{0 . 0}$ \\
\hline & IRS & 2.4 & 2.6 & 2.5 & 0.0 & 0.0 & $\mathbf{0 . 0}$ \\
\hline
\end{tabular}




\section{Figure legends}

Figure 1: Expression of EFNA1 ligand and EphA2 receptor in non-neoplastic human bone and in osteosarcoma tissue samples. (A) EFNA1 expression in osteocytes (red arrow), osteoblasts (black arrow) and osteoclasts (blue arrow) of non-neoplastic bone. (B) EFNA1 expression in osteosarcoma. (C) Strong nuclear expression of EFNA1 in osteosarcoma cells. (D) EphA2 is not expressed in non-neoplastic bone. (E) EphA2 staining was predominantly observed in tumor cells around neoplastic bone formations (black arrow). (F) Weak to moderate cytoplasmic expression of EphA2 in high grade osteosarcoma. LSAB-HRP staining was used.

Figure 2: Expression of EFNB1 ligand in non-neoplastic human bone and in osteosarcoma tissue samples. (A) EFNB1 expression in fetal non-neoplastic bone. (B) EFNB1 is not expressed in adult non-neoplastic bone. (C) EFNB1 expression in conventional osteosarcoma. (D) EFNB1 expression in osteosarcoma metastases. LSAB-HRP staining was used.

Figure 3: Expression of EFNA2 ligand and EFNB3 ligand in conventional and osteosarcoma metastases. (A) EFNA2 expression in conventional osteosarcoma. (B) EFNA2 expression in tumor vessels (arrow). (C) EFNB3 expression in conventional osteosarcoma. (D) EFNB3 expression in osteosarcoma metastases and tumor vessels (arrow). LSAB-HRP staining was used.

Figure 4: Internalization of EphA2 receptor following EFNA1 ligand application. (A) left panel: protein expression of EFNA1 ligand and EphA2 receptor in primary osteoblast cells and in osteosarcoma cell lines. Actin levels served as a loading control. 1: ZK58. 2: MG63. 3: MNNG/HOS. 4: SaOS2. 5: SJSA. 6: OST. 7: HOS. 8: HOBc. Right panel: Semi-quantitative 
evaluation of EphA2 receptor and EFNA1 ligand levels. (B, C) Time-dependent internalization of EphA2 receptor following EFNA1/ $\mathrm{F}_{c}$ application in $\mathrm{SaOS} 2$ and MNNG/HOS cells. EphA2-protein was accumulated in membrane ruffles of SaOS2 (B arrow) and on sites of cell-cell contact in MNNG/HOS cells (C arrow). Nuclei were counterstained with DAPI. Magnification 1,000x.

Figure 5: Activation of P-Erk1/2 via EFNA1-stimulated receptor activation. SaOS2 (A) and MNNG/HOS (B) cells were stimulated with $1 \mu \mathrm{g} / \mathrm{ml}$ EFNA1/F $\mathrm{F}_{\mathrm{c}}$ for the indicated time points. Total cell lysates were blotted for phopspho-tyrosine (PY). The membranes were then stripped and reprobed for EphA2, P-Erk1/2 and Erk1. Lower panel of $A$ and B: For semiquantification of Western blot results, ImageJ was used. ut: untreated cells.

Figure 6: Receptor stimulation via EFNA1 ligand has a limited effect onto cell growth. MNNG/HOS cells were plated on 96-well-plates or polyhema plates and treated with $1 \mu \mathrm{g} / \mathrm{ml}$ EFNA1/ $\mathrm{F}_{\mathrm{c}}$. Anchorage-dependent (A) and anchorage-independent (B) proliferation of cells was measured using a MTT assay and the mean absorbence is shown. As a control, untreated cells were used. MNNG/HOS cells showed slightly increased anchorage-independent proliferation when treated with the soluble ligand. All assays were performed as triplicates and repeated at least 2-times and one representative example is shown. (C) Wound-healing assays of exponentially growing MNNG/HOS cells. Confluent cells were wounded through the central axis following treatment with $1 \mu \mathrm{g} / \mathrm{ml}$ EFNA1// $F_{c}$ or PBS as a control up to $48 \mathrm{~h}$. Migration was analyzed using a phase contrast microscope (Leica). Magnification 200x. All experiments were repeated at least 2-times and one representative example is shown.

Figure 7: Autoregulation of EFNA1 ligand and $\operatorname{EphA2}$ receptor through EFNA1/F treatment and Mek activation. (A) MNNG/HOS cells were treated with $1 \mu \mathrm{g} / \mathrm{ml} \mathrm{EFNA1/F_{c }}$ 
for the time points indicated. RNA were isolated and analyzed via RT-PCR for EFNA1 ligand and for EphA2 receptor expression. Actin levels served as loading control. For semiquantification of RT-PCR results, ImageJ was used. ut: untreated cells. (B) MNNG/HOS cells were treated with $50 \mu \mathrm{M}$ U0126 for $48 \mathrm{~h}(+)$. As a control, cells were treated with the solvent DMSO (-). left panel: Cells were harvested and equal amounts of cell lysates were resolved by SDS-PAGE and analyzed through Western blot for EphA2, EFNA1 and P-Erk1/2 expression. Actin levels served as loading control. right panel: RNA was extracted following RT-PCR reaction for EphA2 and EFNA1 expression. Amplification of Actin as loading control was performed. ut: untreated cells. For semi-quantification of RT-PCR and Western blot results, ImageJ was used. All experiments were repeated at least 2-times and one representative example is shown. 
Figure 1

A

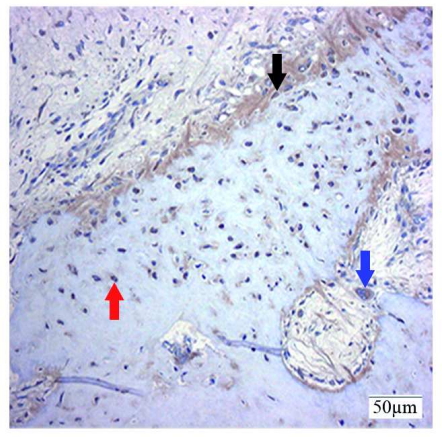

C

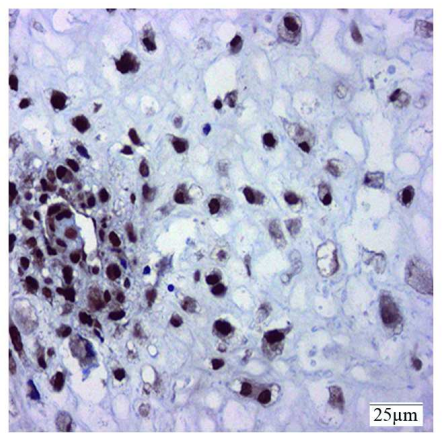

$\mathbf{B}$

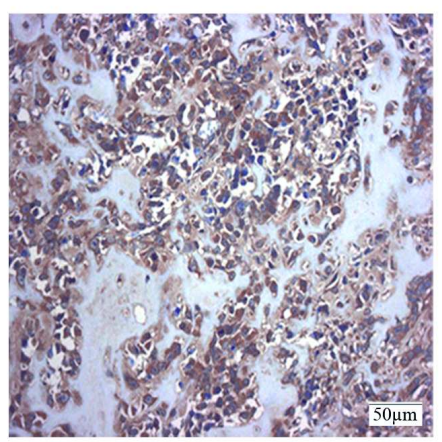

$210 \times 295 \mathrm{~mm}(200 \times 200 \mathrm{DPI})$ 
Figure 1

D

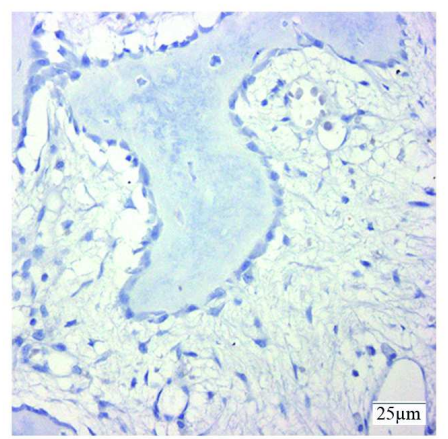

F

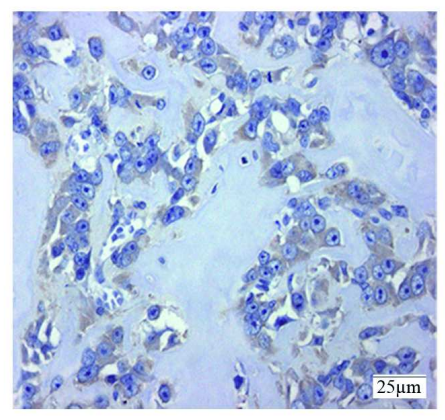

$\mathbf{E}$

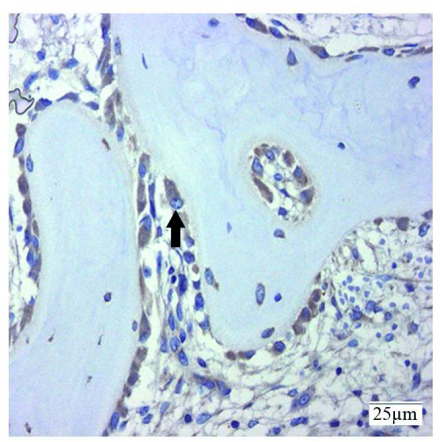

$210 \times 295 \mathrm{~mm}(200 \times 200$ DPI $)$ 
Figure 2

A

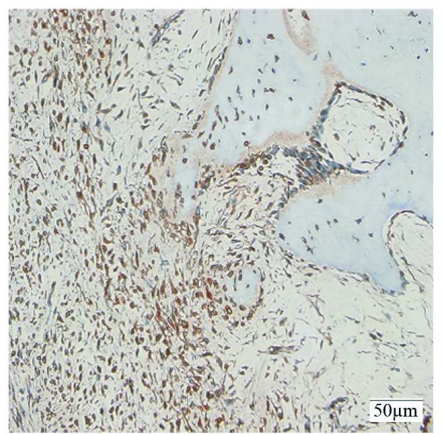

C

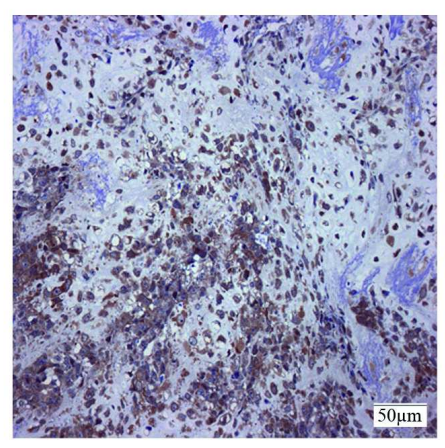

B

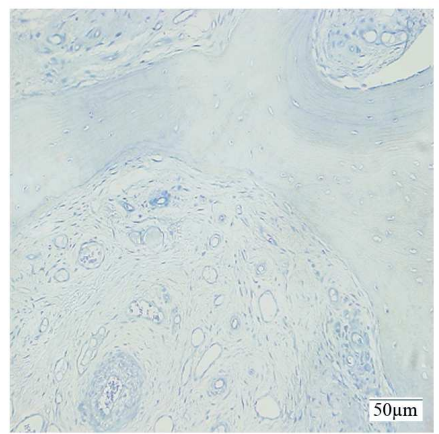

D

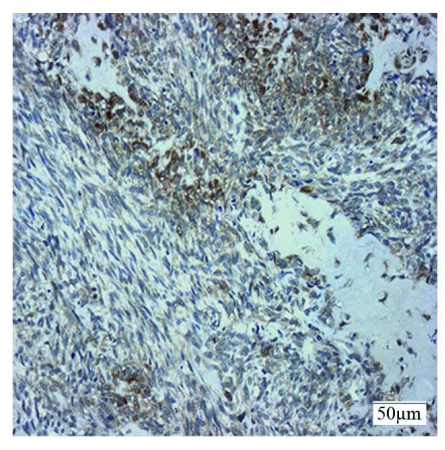

$210 \times 295 \mathrm{~mm}(200 \times 200 \mathrm{DPI})$ 
Figure 3

A

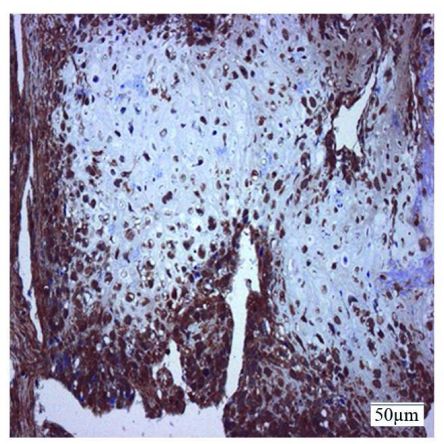

C

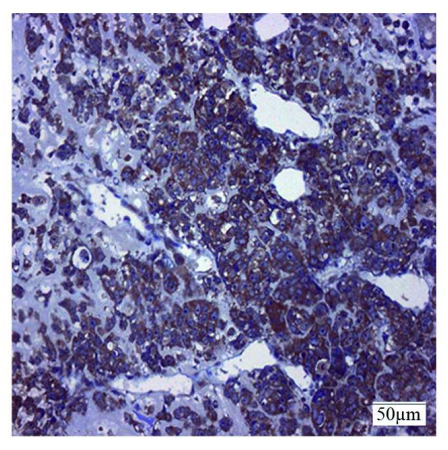

B

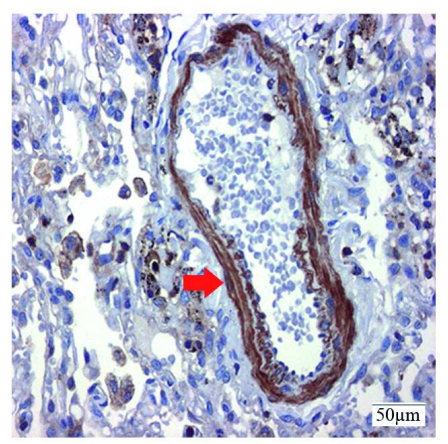

D

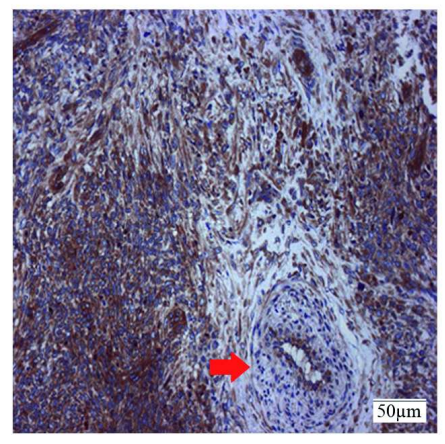

$210 \times 295 \mathrm{~mm}(200 \times 200 \mathrm{DPI})$ 
Figure 4

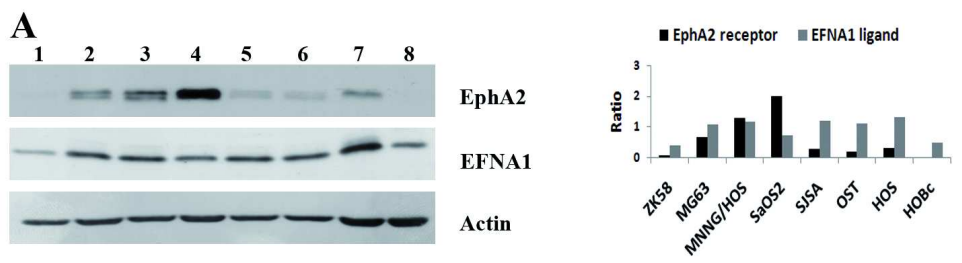

B

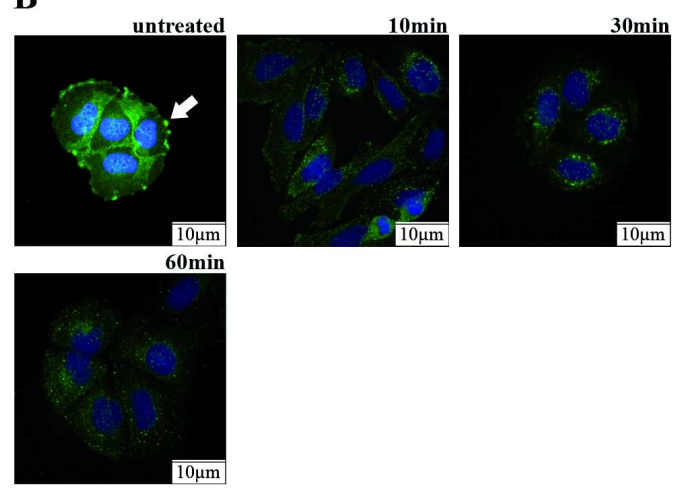

C
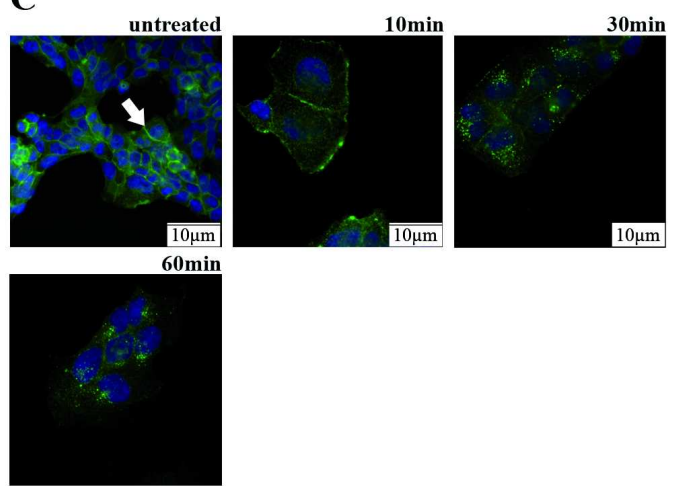

$210 \times 295 \mathrm{~mm}(200 \times 200$ DPI $)$ 


\section{Figure 5}

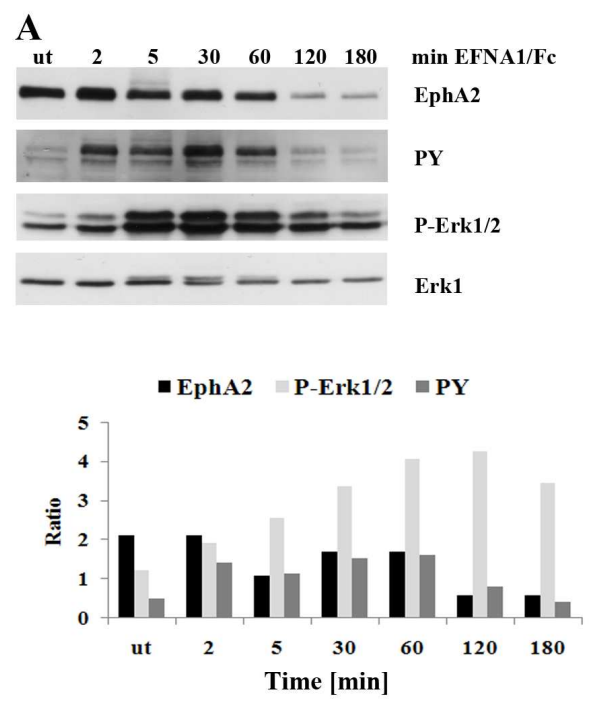

B

$\begin{array}{llllllll}\text { B } & & & & & & & \\ \text { ut } & 2 & 5 & 30 & 60 & 120 & 180 & \min \mathrm{EFNA1} / \mathrm{Fc}\end{array}$
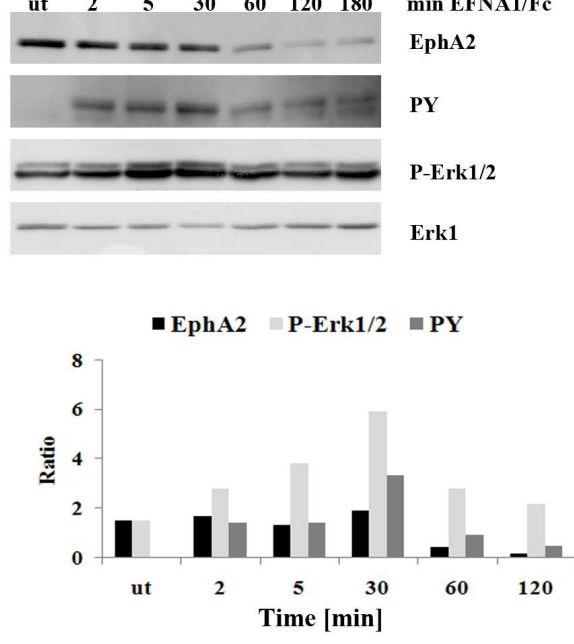

$210 \times 295 \mathrm{~mm}(200 \times 200 \mathrm{DPI})$ 


\section{Figure 6}

A

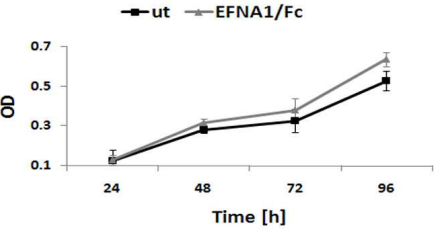

B

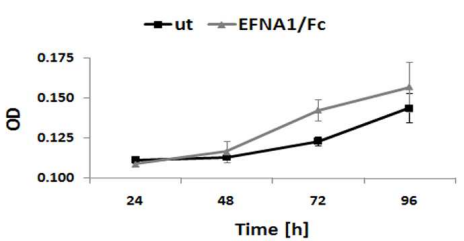

C
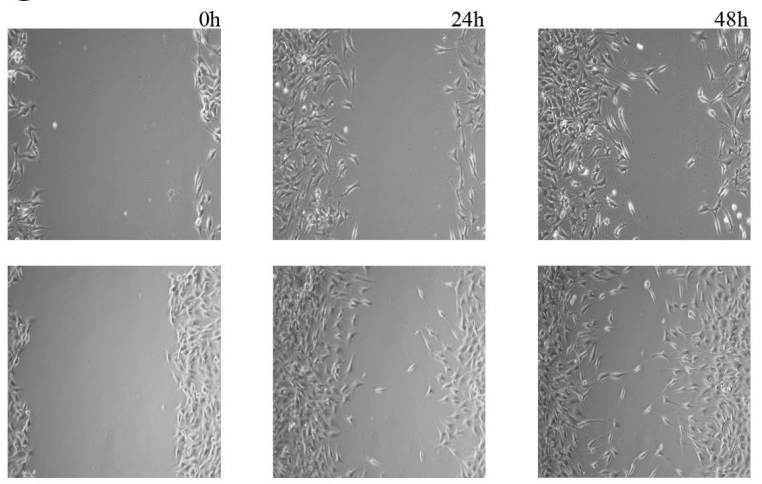

untreated (a)

EFNA1/Fc

$210 \times 295 \mathrm{~mm}(200 \times 200 \mathrm{DPI})$ 
Figure 7

A

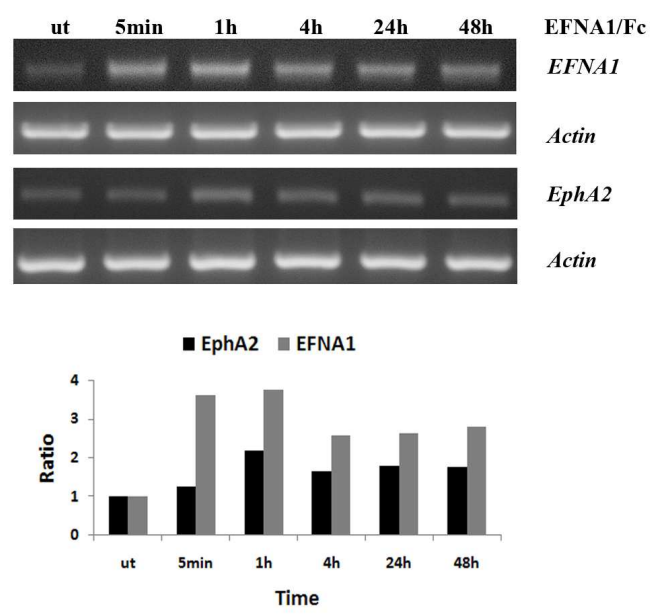

B
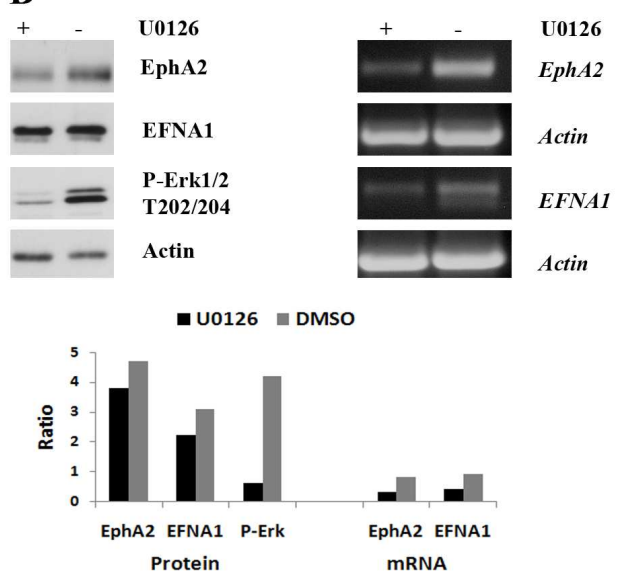

$210 \times 295 \mathrm{~mm}(200 \times 200 \mathrm{DPI})$ 